\title{
FRACTIONATION OF HEMICELLULOSE FROM RICE STRAW BY ALKALINE EXTRACTION AND ETHANOL PRECIPITATION
}

\author{
(Pemisahan Hemiselulosa daripada Hampas Batang Padi melalui Pengekstrakan Beralkali dan \\ Pemendakan Etanol)
}

\author{
Nur Hazlilla Zulyadi, Sabiha Hanim Saleh*, Siti Halimah Sarijo \\ School of Chemistry and Environment, Faculty of Applied Sciences, \\ Universiti Teknologi MARA (UiTM), 40450 Shah Alam, Selangor, Malaysia
}

*Corresponding author: sabihahanim@salam.uitm.edu.my

Received: 24 February 2015; Accepted: 27 October 2015

\begin{abstract}
Hemicelluloses were extracted from rice straw using alkaline extraction and ethanol precipitation. The effects of different extraction conditions; temperature $\left(45-65^{\circ} \mathrm{C}\right), \mathrm{pH}(4.5-6.5)$, and concentrations of $\mathrm{NaOH}(0.25-1 \mathrm{M})$ on the hemicellulose yield were investigated. Two hemicelllulosic fractions namely $\mathrm{Ha}_{1}$ and $\mathrm{Ha}_{2}$ were obtained by precipitation of alkaline soluble hemicellulose in 0.2 volumes and 4 volumes ethanol, respectively. The $\mathrm{Ha}_{1}$ and $\mathrm{Ha}_{2}$ were further characterized to obtain total sugar, monosaccharides and Klason Lignin content. The highest hemicellulose yield for $\mathrm{Ha}_{1}$ was $4.00 \%$ obtained at $55{ }^{\circ} \mathrm{C}$ and $\mathrm{pH} 5.5$ with $0.25 \mathrm{M}$ of $\mathrm{NaOH}$, whereas the highest hemicellulose yield for $\mathrm{Ha}_{2}$ was $19.88 \%$ obtained at $55{ }^{\circ} \mathrm{C}$ and $\mathrm{pH} 5.5$ with $0.5 \mathrm{M}$ of $\mathrm{NaOH}$. This study revealed that hemicellulose yield is dependent on the $\mathrm{pH}$, temperature and concentration of $\mathrm{NaOH}$ in the alkaline extraction.
\end{abstract}

Keywords: hemicelluloses, rice straw, alkaline extraction, ethanol precipitation

\begin{abstract}
Abstrak
Hemiselulosa daripada hampas batang padi telah diekstrak melalui pengekstrakan beralkali dan pemendakan etanol. Kesan perbezaan kondisi pengekstrakan; suhu $\left(45-65{ }^{\circ} \mathrm{C}\right)$, $\mathrm{pH}(4.5-6.5)$, dan kepekatan $\mathrm{NaOH}(0.25-1 \mathrm{M})$ ke atas hasil hemiselulosa dikaji. Dua pecahan hemiselulosa, $\mathrm{Ha}_{1}$ and $\mathrm{Ha}_{2}$ telah diperolehi melalui pemendakan hemisellulosa larut alkali dalam isipadu etanol 0.2 dan 4 masing-masing. $\mathrm{Ha}_{1}$ and $\mathrm{Ha}_{2}$ dicirikan oleh jumlah gula, kandungan monosakarida dan Klason Lignin. Hasil hemiselulosa tertinggi untuk $\mathrm{Ha}_{1}$ adalah $4.00 \%$ yang diperolehi pada suhu $55{ }^{\circ} \mathrm{C}$, pH 5.5 and $0.25 \mathrm{M} \mathrm{NaOH}$, manakala untuk $\mathrm{Ha}_{2}$ adalah $19.88 \%$ diperolehi pada suhu $55^{\circ} \mathrm{C}$, pH 5.5 and kepekatan $0.5 \mathrm{M} \mathrm{NaOH}$. Kajian ini membuktikan hasil hemisellulosa bergantung kepada $\mathrm{pH}$, suhu dan kepekatan $\mathrm{NaOH}$ dalam pengekstrakan beralkali.
\end{abstract}

Kata kunci: hemiselulosa, hampas batang padi, pengekstrakan beralkali, pemendakan etanol

\section{Introduction}

The main cereal crop in the whole wide world is rice, which is being produced in more than 148 million hectares with huge range of ecosystem. The scientific name of paddy is Oryza sativa. It is an important cereal crop that produce a lot of residues which is rice straw [1]. Rice straw is the rice plant stalk that is left as waste product on the field after harvesting of the rice grain [2]. A lot of rice straw are disposed by biomass burning that leads to air pollution.Therefore, a lot of research work has been performed to find ways of utilizing these agricultural waste. Hemicellulose is the second most abundant polysaccharide in nature, representing approximately 20-30\% of 


\section{Nur Hazlilla et al: FRACTIONATION OF HEMICELLULOSE FROM RICE STRAW BY ALKALINE EXTRACTION AND ETHANOL PRECIPITATION}

lignocellulosic biomass [3]. Hemicellulose polymers are complex components in the plants cell wall. With cellulose and lignin, hemicellulose form hydrogen bonds and covalent bond respectively.

The hemicelluloses are used in various industrial applications such as food additives, biodegradable films and in medicinal applications [4]. Various methods were used to isolate hemicellulose from the agricultural waste. Among these methods, alkaline extraction is most widely used. Alkaline solution hydrolyzes the ester linkage between hemicellulose and other components, resulted in isolating hemicellulose in the aqueous media. Usually the isolation of hemicellulose is done by using alkaline solution such as $\mathrm{NaOH}$ for softwood and $\mathrm{KOH}$ for hardwood [5]. The aim of this study was to optimize the alkaline extraction conditions and ethanol precipitation of hemicelluloses from rice straw. The effects of the concentration of $\mathrm{NaOH}$, temperature and $\mathrm{pH}$ on hemicellulose percentage yield were investigated.

\section{Materials}

\section{Materials and Methods}

Rice straw was obtained from local sources (Perlis, Malaysia). It was dried and cut into small pieces. The straw was ground to pass a $0.08 \mathrm{~mm}$ size screen and stored at room temperature. All other chemicals used were of analytical grade unless otherwise stated.

\section{Extraction of hemicelluloses}

Extraction of hemicellulose was carried out by mixing the rice straw with $0.25 \mathrm{M}$ sodium hydroxide $(\mathrm{NaOH})$ with ratio of 1:25 (w/v). The mixture was stirred at $400 \mathrm{rpm}$ and heated at constant temperature of $55{ }^{\circ} \mathrm{C}$ for 2 hours. After filtration, the $\mathrm{pH}$ of the solution was adjusted to $\mathrm{pH} 5.5$ by adding $6 \mathrm{M}$ hydrochloric acid $(\mathrm{HCl})$. Then the mixtures were kept at $4.0{ }^{\circ} \mathrm{C}$ for 24 hours. The mixture was then centrifuged at $3500 \mathrm{rpm}$ for 15 minutes. Ethanol 0.2 volumes and 4 volumes containing $10 \%$ of acetic acid were added to the liquid fraction to precipitate $\mathrm{Ha}_{1}$ and $\mathrm{Ha}_{2}$ respectively. Both hemicellulose fractions $\left(\mathrm{Ha}_{1}\right.$ and $\left.\mathrm{Ha}_{2}\right)$ were obtained and dried at $40.0{ }^{\circ} \mathrm{C}$ for 24 hours. In order to optimize the alkaline extraction conditions, the extraction was carried out at various concentration of $\mathrm{NaOH}$ $(0.25 \mathrm{M}, 0.5 \mathrm{M}$ and $1 \mathrm{M})$ temperature $\left(45^{\circ} \mathrm{C}, 55^{\circ} \mathrm{C}\right.$, and $\left.65^{\circ} \mathrm{C}\right)$ and $\mathrm{pH}(4.5,5.5$ and 6.5$)$.

\section{Analytical method}

Total sugar content was measured according to phenol-sulphuric acid method [6]. The hemicellulose fraction with unknown concentration was added with $0.5 \mathrm{~mL}$ of $5.0 \%$ phenol solution and the mixture was shaken. A volume of $2.5 \mathrm{~mL}$ concentrated $\mathrm{H}_{2} \mathrm{SO}_{4}$ was quickly added to the mixture (phenol-hemicellulose) and shaken once again. These solutions were then analysed where the absorbance of the mixtures were recorded at $480 \mathrm{~nm}$ using UV-Visible spectrophotometer. The hemicelluloses yield (\%) was calculated based on total sugar content in the hemicelluloses fraction. The monosaccharides sugar was determined by using a high performance liquid chromatography (HPLC) (Agilent Technologies 1200 Series, Germany) using Aminex HPX 87P column (300 mm x $7.8 \mathrm{~mm}$ ). The HPLC was equipped with a refractive index detector (G 1362A, Agilent Technologies 1200 Series, Germany) and column oven (Agilent Technologies 1200 Series, Germany). The hemicellulose fraction was filtered through a $0.20 \mu \mathrm{m}$ nylon syringe filter (Minisart, Sartorius AG, Germany) prior directly injected to the HPLC system. The hemicellulose fractions were eluted using deionised water as the mobile phase at column temperature of $80{ }^{\circ} \mathrm{C}$ and a flow rate of $0.5 \mathrm{~mL} / \mathrm{min}$. Klason lignin content was determined following TAPPI method T222. The FTIR spectra of the hemicellulose fractions were obtained on a FT-IR spectroscopy (Nicolet 500) using a $\mathrm{KBr}$ disc containing $1 \%$ finely ground samples. Spectra were recorded between 4000 and $400 \mathrm{~cm}^{-1}$ at a resolution of $4 \mathrm{~cm}^{-1}$.

\section{Statistical analysis}

ANOVA was used to analyse the data of experiment and Duncan's multiple range test was applied in order to determine the significant difference $(\mathrm{P}<0.05)$ of samples using Statistical Package for Social Science, Version 10 (SPSS Inc., Illinois). The result was expressed as mean \pm SD (standard deviation).

\section{Effect of $\mathrm{NaOH}$ concentration}

\section{Results and Discussion}

Alkaline extraction was carried out to investigate the effects of $\mathrm{NaOH}$ concentrations; $0.25 \mathrm{M}, 0.5 \mathrm{M}$ and $1 \mathrm{M}$ on hemicellulose yield, while other parameters were fixed as followed : pH 5.5 and temperature $55{ }^{\circ} \mathrm{C}$. As shown in 
Figure 1 (a), hemicellulose yield for both $\mathrm{Ha}_{1}$ and $\mathrm{Ha}_{2}$ increased as $\mathrm{NaOH}$ concentration increased from $0.25 \mathrm{M}$ to $0.5 \mathrm{M}$ but then decreased tremendously when the $\mathrm{NaOH}$ concentration was increased to $1 \mathrm{M}$. This indicates that hemicellulose extraction was best performed at mild conditions. Hemicellulose yield for both, $\mathrm{Ha}_{1}$ and $\mathrm{Ha}_{2}$ were highest at $0.5 \mathrm{M} \mathrm{NaOH}$ concentration. Statistical analysis for $\mathrm{Ha}_{1}$ showed that there were no significant differences between $0.25 \mathrm{M} \mathrm{NaOH}$ and $0.5 \mathrm{M} \mathrm{NaOH}(\mathrm{P}>0.05)$, while there were significant differences among $0.25 \mathrm{M} \mathrm{NaOH}$ and $1 \mathrm{M} \mathrm{NaOH}$. Thus $0.25 \mathrm{M} \mathrm{NaOH}$ concentration was chosen for further analysis for $\mathrm{Ha}_{1}$. On the other hand, the statistical analysis for $\mathrm{Ha}_{2}$ showed that there were significant differences between $0.25 \mathrm{M}, 0.5 \mathrm{M}$ and $1 \mathrm{M} \mathrm{NaOH}$ $(\mathrm{P}<0.05)$.Therefore, $0.5 \mathrm{M} \mathrm{NaOH}$ concentration was chosen for further analysis for $\mathrm{Ha}_{2}$.

\section{Effect of temperature}

The effects of different temperatures $\left(45-65^{\circ} \mathrm{C}\right)$ on the yield of hemicellulosic fractions; $\mathrm{Ha}_{1}$ and $\mathrm{Ha}_{2}$ were studied while the other parameters were fixed; $\mathrm{pH} 5.5$ with $0.25 \mathrm{M} \mathrm{NaOH}$ for $\mathrm{Ha}_{1}$ and $\mathrm{pH} 5.5$ with $0.5 \mathrm{M} \mathrm{NaOH}$ for $\mathrm{Ha}_{2}$. Statiscal analysis of hemicellulose yield, $\mathrm{Ha}_{1}$ and $\mathrm{Ha}_{2}$ showed that the significant difference existence between temperature of $45{ }^{\circ} \mathrm{C}$ and $55{ }^{\circ} \mathrm{C}$ and among hemicellulose extracted at $55^{\circ} \mathrm{C}$ and $65^{\circ} \mathrm{C}(\mathrm{P}<0.05)$, however there is no significant difference between hemicellulose yield extracted at $45{ }^{\circ} \mathrm{C}$ and $65{ }^{\circ} \mathrm{C}(\mathrm{P}>0.05)$. Based on Figure 1 (b), the best temperature for alkaline extraction was at $55^{\circ} \mathrm{C}$ which gave the highest hemicellulose yield. The presence of high lignin content hindered the yield of hemicellulose in $\mathrm{Ha}_{1}$ resulted in lower hemicellulose yield than $\mathrm{Ha}_{2}$. The hemicellulose yield for both $\mathrm{Ha}_{1}$ and $\mathrm{Ha}_{2}$ significantly increased from $45{ }^{\circ} \mathrm{C}$ to $55{ }^{\circ} \mathrm{C}$ and as temperature of extraction reached $65^{\circ} \mathrm{C}$, the yield of hemicelluloses significantly decreased. The yield of hemicellulose decreased at $65{ }^{\circ} \mathrm{C}$ due to less degradation of macromolecular hemicellulose. The minor degradation occurred mainly because of the linkages between glycosyl units were cleaved at high temperature [6].

\section{Effect of pH}

$\mathrm{pH}$ was another factor which affected the efficiency of hemicellulose extraction. The effect of $\mathrm{pH}$ for hemicellulosic fractions, $\mathrm{Ha}_{1}$ and $\mathrm{Ha}_{2}$ were studied at different $\mathrm{pH}(4.5-6.5)$ while the other parameters were fixed; $0.25 \mathrm{M} \mathrm{NaOH}$ and temperature of $55{ }^{\circ} \mathrm{C}$ for $\mathrm{Ha}_{1}$ while $0.5 \mathrm{M} \mathrm{NaOH}$ and temperature of $55{ }^{\circ} \mathrm{C}$ for $\mathrm{Ha}_{2}$. Statiscal analysis for $\mathrm{Ha}_{1}$ and $\mathrm{Ha}_{2}$ showed that the significant difference existence between $\mathrm{pH}$ of 4.5 and 5.5 and between $\mathrm{pH} 5.5$ and 6.5 , $(\mathrm{P}<0.05)$, however there is no significant difference between $\mathrm{pH} 4.5$ and $6.5(\mathrm{P}>0.05)$. There was an increasing trend in hemicellulose yield from $\mathrm{pH} 4.5$ to 5.5 and decreasing trend from $\mathrm{pH} 5.5$ to 6.5 for both $\mathrm{Ha}_{1}$ and $\mathrm{Ha}_{2}$. This indicated that minor degradation occurred when the $\mathrm{pH}$ was slightly acidic $(\mathrm{pH} 4.5)$ and at neutral condition $(\mathrm{pH}$ 6.5). Figure 1 (c) showed that the suitable $\mathrm{pH}$ to yield the maximum concentration for both $\mathrm{Ha}_{1}$ and $\mathrm{Ha}_{2}$ was at $\mathrm{pH}$ 5.5. Thus, $\mathrm{pH} 5.5$ was favorable to isolate hemicellulose from rice straw using alkaline extraction.

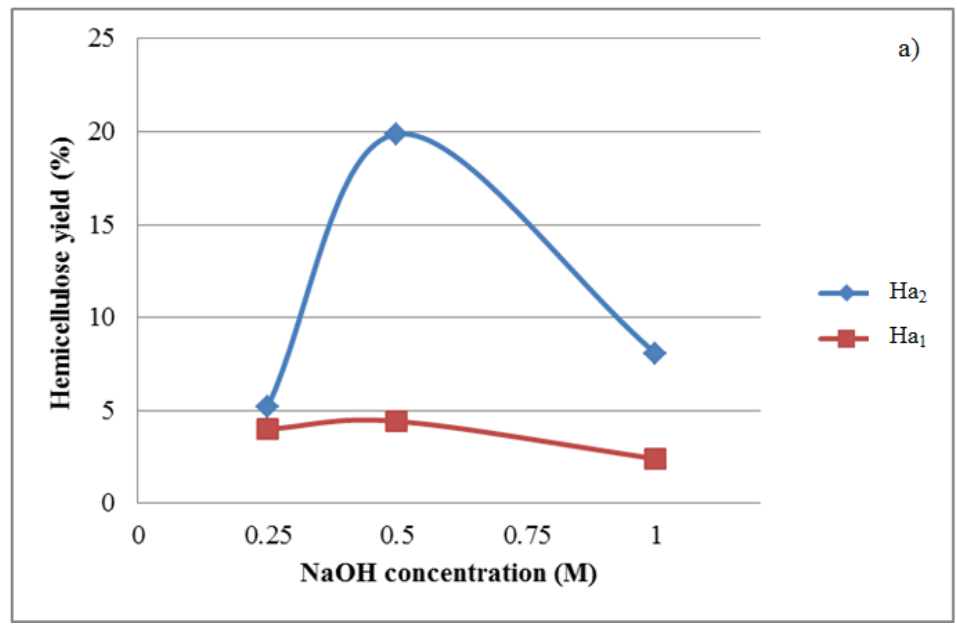


Nur Hazlilla et al: FRACTIONATION OF HEMICELLULOSE FROM RICE STRAW BY ALKALINE EXTRACTION AND ETHANOL PRECIPITATION
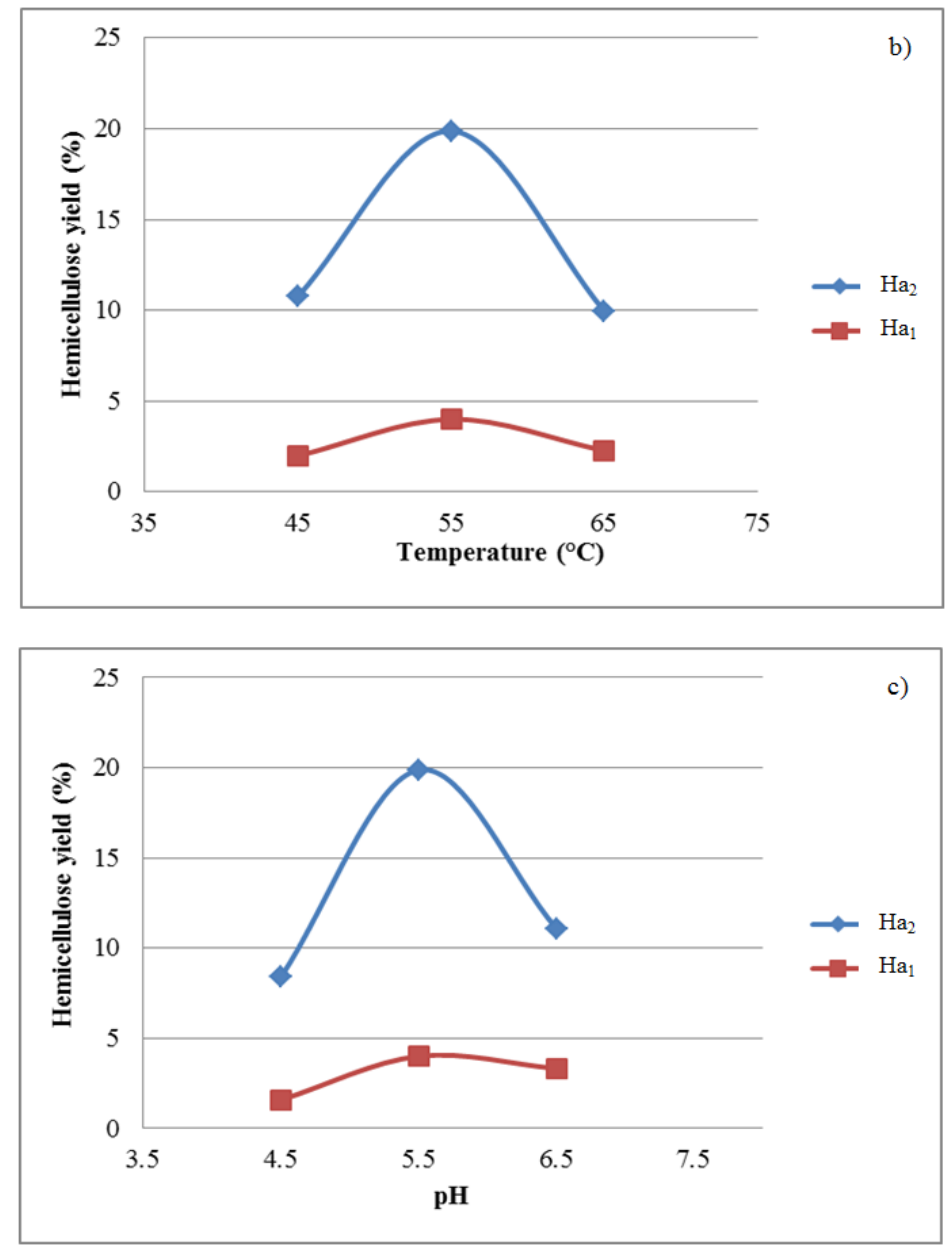

Figure 1. Effects of $\mathrm{NaOH}$ concentration (a), temperature (b), and $\mathrm{pH}(\mathrm{c})$ on hemicellulose yield (\%) $\mathrm{Ha}_{1}$ and $\mathrm{Ha}_{2}$.

\section{Klason Lignin content}

The Klason lignin content for both hemicellulose fractions, $\mathrm{Ha}_{1}$ and $\mathrm{Ha}_{2}$ is shown in Table 1. The result showed that $\mathrm{Ha}_{1}$ contain more lignin $(11.72 \%)$ than $\mathrm{Ha}_{2}(4.22 \%)$. Table 1 showed that as the volume of ethanol decreased $(0.2 \mathrm{v})$ in $\mathrm{Ha}_{1}$, the Klason lignin content increased and as the volume of ethanol increased $(4 \mathrm{v})$ in $\mathrm{Ha}_{2}$, the $\mathrm{Klason}$ lignin content decreased. The increased volume of ethanol $(4 \mathrm{v})$ increased the polarity of plant cell wall in $\mathrm{Ha}_{2}$ exposed it more to the solvent thus promote the lignin removal [7].

Table 1. Monosaccharide composition and Klason Lignin content for $\mathrm{Ha}_{1}$ and $\mathrm{Ha}_{2}$

\begin{tabular}{|c|c|c|c|c|c|}
\hline & $\begin{array}{l}\text { Glucose } \\
(\mathbf{m g} / \mathbf{m L})\end{array}$ & Arabinose (mg/mL) & $\begin{array}{c}\text { Xylose } \\
(\mathbf{m g} / \mathbf{m L})\end{array}$ & Ara/Xyl ratio & $\begin{array}{c}\text { Klason Lignin } \\
(\%)\end{array}$ \\
\hline $\mathrm{Ha}_{1}$ & $0.57 \pm 0.44$ & $0.10 \pm 0.02$ & $0.27 \pm 0.02$ & 0.36 & $11.72 \pm 5.07$ \\
\hline $\mathrm{Ha}_{2}$ & $0.70 \pm 0.18$ & $0.96 \pm 0.07$ & $0.05 \pm 0.05$ & 21.08 & $4.22 \pm 1.32$ \\
\hline
\end{tabular}


Monosaccharide analysis by HPLC

As shown in Table 1 , both $\mathrm{Ha}_{1}$ and $\mathrm{Ha}_{2}$ composed of glucose, arabinose and xylose. The predominant sugar component for $\mathrm{Ha}_{1}$ was glucose while for $\mathrm{Ha}_{2}$ was arabinose. $\mathrm{Ha}_{2}$ consisted of higher glucose concentration mainly because the presence of glucans which associated with xylans in primary cell wall, which were less associated with lignin. The xylose concentration higher in $\mathrm{Ha}_{1}$ as compared to $\mathrm{Ha}_{2}$. The lower amount of arabinose in $\mathrm{Ha}_{1}$ suggested that the hemicellulose was closely assosiated to the cellulose surface [8]. Hemicellulose fraction, $\mathrm{Ha}_{2}$ contained higher amount of Ara/Xyl (21.08) whereas $\mathrm{Ha}_{1}$ showed lower Ara/Xyl ratio (0.36). Higher amount of Ara/Xyl means that the hemicellulose obtained more linear arabinoxylan while lower Ara/Xyl ratio consisted of branched arabinoxylan [9].

\section{FTIR Spectra}

Figure 2 shows the FTIR spectra of hemicellulosic fractions $\left(\mathrm{Ha}_{1}, \mathrm{Ha}_{2}\right)$ and rice straw within the region of 500 $4000 \mathrm{~cm}^{-1}$ including region $850-1200 \mathrm{~cm}^{-1}$ which is typical region for hemicellulose [10]. Both hemicellulose fractions show similar features. All of the spectra showed similarity as they all have hemicellulose band $(850-1200$ $\mathrm{cm}^{-1}$ ), which concluded that the alkaline extraction did not change the macromolecular structure of hemicellulose. Absorption band at $1610 \mathrm{~cm}^{-1}$ corresponded to the water bending mode presence for only $\mathrm{Ha}_{1}$ and $\mathrm{Ha}_{2}$ since hemicellulose have strong affinity towards water whereas, this band could not found in rice straw due to the presence of cellulose which hindered the water affinity [11]. Low intensity absorption band at region $850-1200$ $\mathrm{cm}^{-1}$ in $\mathrm{Ha}_{1}$ compared to $\mathrm{Ha}_{2}$ shows low purity of hemicellulose fraction due to the higher lignin content for $\mathrm{Ha}_{1}$ compared to $\mathrm{Ha}_{2}$. The absoption band at region between $1126-1032 \mathrm{~cm}^{-1}$ is a typical band for lignin [12]. Higher intensity absorption band at region $1126-1032 \mathrm{~cm}^{-1}$ in $\mathrm{Ha}_{1}$ compared to $\mathrm{Ha}_{2}$, proved that lignin content was higher in $\mathrm{Ha}_{1}$. The presence of absorption band at $1710 \mathrm{~cm}^{-1}$ in $\mathrm{Ha}_{1}$ is due to the carboxyl groups as the hydroxyl groups in lignin undergo oxidation [13]. Absorption band at $3049 \mathrm{~cm}^{-1}$ is assigned to the $\mathrm{C}-\mathrm{H}$ in an aromatic vibration as hemicellulose contained a small amount of lignin [10]. Absorption band at $1043 \mathrm{~cm}^{-1}$ is due to the C-O-C stretching glycosidic linkages in xylans. And the absorption band at $1740 \mathrm{~cm}^{-1}$ refer to acetyl carbonyl. As shown in Figure 2, broad absorption band at 3400 and $2400 \mathrm{~cm}^{-1}$ is due to the stretching vibrations of $\mathrm{OH}$ and $\mathrm{CH}$ respectively and absorption band at $1200 \mathrm{~cm}^{-1}$ refer to the stretching vibrations of $\mathrm{C}-\mathrm{O}$. The $\mathrm{C}-\mathrm{H}$ bending vibration shows absoption bands at 1467 and $1427 \mathrm{~cm}^{-1}$ while the $\mathrm{OH}$ bending vibration shows absoption bands at $1340 \mathrm{~cm}^{-1}$ [14].

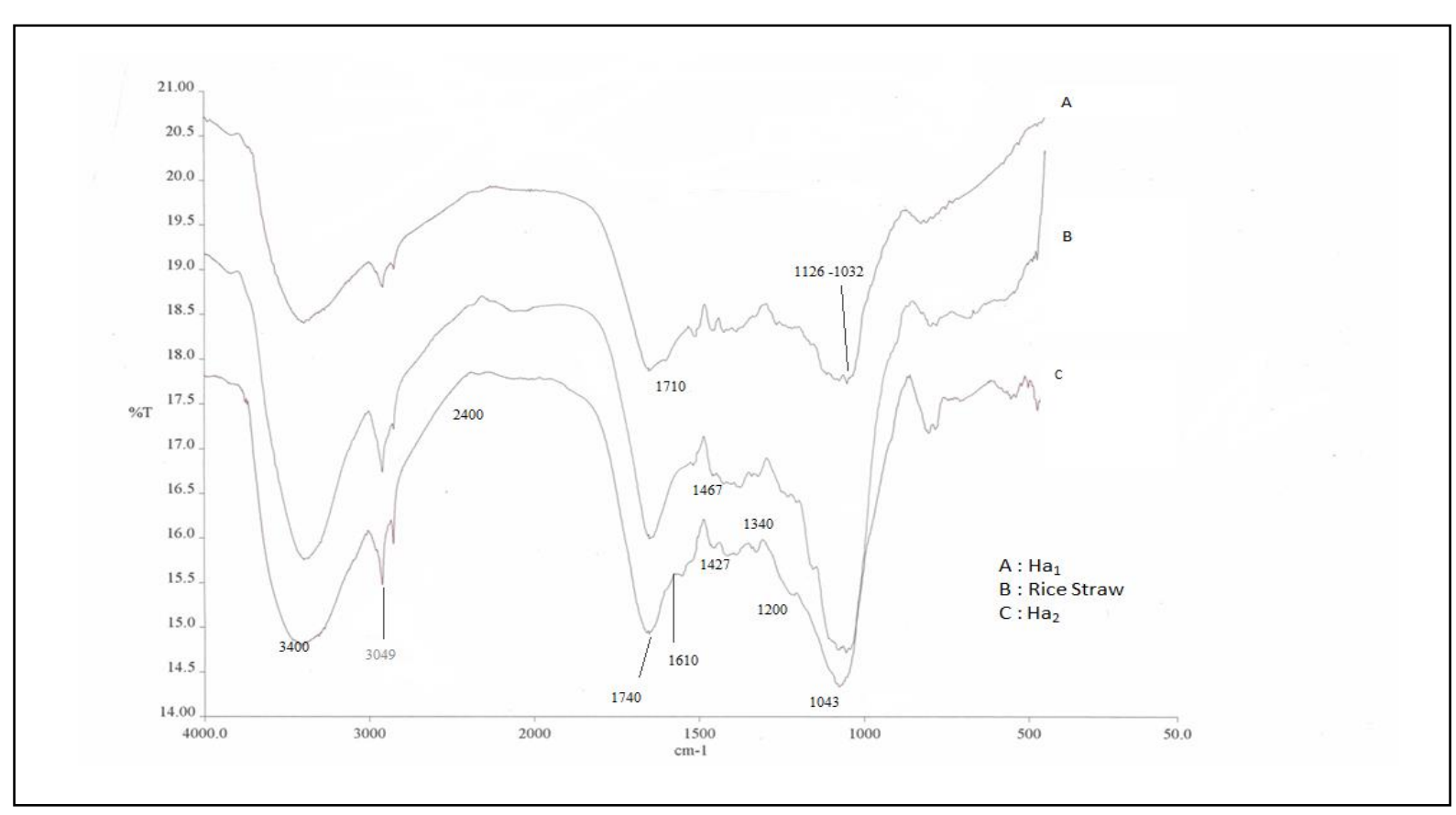

Figure 2. FTIR spectra of $\mathrm{Ha}_{1}, \mathrm{Ha}_{2}$ and rice straw 


\section{Nur Hazlilla et al: FRACTIONATION OF HEMICELLULOSE FROM RICE STRAW BY ALKALINE EXTRACTION AND ETHANOL PRECIPITATION}

\section{Conclusion}

This study showed that the maximum hemicellulose percentage yield was obtained by alkaline extraction. The highest hemicellulose yield for $\mathrm{Ha}_{1}$ was $4.00 \%$ obtained at $55^{\circ} \mathrm{C}$ and $\mathrm{pH} 5.5$ with $0.25 \mathrm{M} \mathrm{NaOH}$, whereas the highest hemicellulose percentage yield for $\mathrm{Ha}_{2}$ was $19.88 \%$ obtained at $55{ }^{\circ} \mathrm{C}$ and $\mathrm{pH} 5.5$ with $0.5 \mathrm{M}$ of $\mathrm{NaOH}$. Hemicellulose yield $\mathrm{Ha}_{2}$ was found to be higher than $\mathrm{Ha}_{1}$, showing that lignin content affected the percentage yield of hemicellulose.

\section{Acknowledgement}

The authors are grateful to the Universiti Teknologi MARA, Malaysia for the financial support of this research by ZAMALAH Sokongan Pasca Siswazah (Postgraduate Supporting Fellowship), 600-RMI/DANA 5/3/PSF (18/2015), and Faculty of Pharmacy, University Teknologi Mara, Puncak Alam for HPLC facilities.

\section{References}

1. Sharma, R. K. and Arora, D. S. (2010). Biodegradation of paddy straw obtained from different geographic locations by means of Phlebia spp. for animal feed. Biodegradation, 22: 143 - 152.

2. Lim, J. S., Abdul Manan, Z., Wan Alwi, S. R. and Hashim, H. (2012). A review on utilisation of biomass from rice industry as a source of renewable energy. Renewable and Sustainable Energy Reviews, 16(5): 3084 - 3094.

3. Ebringerová, A., Hromádková, Z., Híbalová, V., Xu, C., Holmbom, B., Sundberg, A., and Willför, S. (2007). Norway spruce galactoglucomannans exhibiting immunomodulating and radical-scavenging activities. International Journal of Biology Macromolecule, 42: 1 - 5 .

4. Sabiha-Hanim, S. and Siti-Norsafurah, A. M. (2012). Physical properties of hemicellulose films from sugarcane bagasse. Procedia Engineering, 42: 1390 - 1395.

5. Peng, P., Peng, F., Bian, J., Xu, F., Sun, R.-C. and Kennedy, J. F. (2011).Isolation and structural characterization of hemicelluloses from the bamboo species Phyllostachysincarnata Wen. Carbohydrate Polymers, 86(2): $883-890$.

6. Bian, J., Peng, F., Peng, X.-P., Xu, F., Sun, R.-C. and Kennedy, J. F. (2012). Isolation of hemicelluloses from sugarcane bagasse at different temperatures: Structure and properties. Carbohydrate Polymers, 88(2): $638-$ 645.

7. Yang, D., Zhong, L-X., Yuan, T-Q., Peng, X-W. and Sun, R-C. (2013). Studies on the structural characterization of lignin, hemicelluloses and cellulose fractionated by ionic liquid followed by alkaline extraction from bamboo. Industrial Crops and Products, 43: 141 - 149.

8. Xiao, B., Sun, X. and Sun, R. (2001). Chemical, structural, and thermal characterizations of alkali-soluble lignins and hemicelluloses, and cellulose from maize stems, rye straw, and rice straw. Polymer Degradation and Stability, 74(2): $307-319$.

9. Egüés, I., Eceiza, A. and Labidi, J. (2013). Effect of different hemicelluloses characteristics on film forming properties. Industrial Crops and Products, 47: $331-338$.

10. Rabetafika, H. N., Bchir, B., Blecker, C., Paquot, M. and Wathelet, B. (2014). Comparative study of alkaline extraction process of hemicelluloses from pear pomace. Biomass and Bioenergy, 61: 254-264.

11. Kacurakova, M., Belton, P. S., Wilson, R. H. and Hirsch, J. (1998). Hydration properties of xylan-type structure: an FTIR study of xylooligosaccharides. Journal Science of Food and Agriculture, 77(1): 38 - 48.

12. Cai, Y., Li, G., Nie, J., Lin, Y., Nie F. and Zhang, J. (2010). Study of the structure and biosynthetic pathway of lignin in stone cells of pear. Science Horticulturae, 125()3: $374-379$.

13. Sun, R. C., Tomkinson, J., Ma, P. L. and Liang, S. F. (2000). Comparative study of hemicelluloses from rice straw by alkali and hydrogen peroxide treatments. Carbohydrate Polymers, 42(2): $111-122$.

14. Kacuráková, M., Ebringerova, A., Hirsch, J. and Horomadkova, Z. (1994). Infrared study of arabinoxylans. Journal Science of Food Agriculture, 66 (3): 423 - 427. 